\title{
Selective foraging by harp seals Phoca groenlandica in nearshore and offshore waters of Newfoundland, 1993 and 1994
}

\author{
John W. Lawson ${ }^{1, *}$, John T. Anderson ${ }^{2}$, Edgar L. Dalley ${ }^{2}$, Garry B. Stenson ${ }^{2}$ \\ 'Ocean Sciences Centre, Memorial University, St. John's, Newfoundland A1C 5S7, Canada \\ ${ }^{2}$ Department of Fisheries \& Oceans, Science Branch, St. John's, Newioundland A1C 5X1, Canada
}

\begin{abstract}
The harp seal Phoca groenlandica, which is numerous and widespread in the Northwest Atlantic, may have significant influences on the structure of this ecosystem. To quantify this influence, we must understand the functional relationship between harp seals and their prey. If seals are discriminating in their choice of prey, then their consumption of a particular species will not necessarily vary in relation to its availability or catchability. By applying Chesson's index of selectivity to stomach contents and research trawl data collected in several near-and offshore locations, we found that harp seals preferentially selected capelin Mallotus villosus relative to other prey species, irrespective of their local abundance, when given the choice. Arctic cod Boreogadus saida were also preferred in nearshore areas, but not in the offshore. In general, these predators were neutrally selective towards Atlantic cod Gadus morhua, American plaice Hippoglossoides platessoides and Greenland halibut Reinhardtius hippoglossoides. These patterns rationalize the dietary patterns reported for harp seals generally. They also explain the harp seals' switch from a reliance on capelin to Arctic cod seen in the mid 1980s, when evidence suggests these cod became more abundant than capelin in nearshore waters (where their respective energy densities are similar).
\end{abstract}

KEY WORDS: Harp seal - Arctic cod · Capelin · Chesson's selectivity index

\section{INTRODUCTION}

In the Northwest Atlantic, harp seals Phoca groenlandica are very abundant (Reijnders et al. 1993) and have a broad distribution which encompasses coastal and offshore waters from the Gulf of St. Lawrence to the southern Arctic (Sergeant 1965, Finley et al. 1990, Stenson \& Kavanagh 1993). To understand their role in shaping the structure of this marine community we need to know the types and quantities of prey they consume. Since the local abundance and distribution of most fish species are dynamic, and their energy density is seasonally, geographically and morphometrically variable (Steimle \& Terranova 1985, Mårtensson et al. 1996, Lawson et al. 1998), it is likely that harp seals are selective as to which prey they consume from the suite of those available. It has been proposed that

·E-mail: johnwl@morgan.ucs.mun.ca harp seals migrate great distances to establish or maintain contact with preferred prey stocks (Finley et al. 1990, Lawson \& Stenson 1995), or to take advantage of localized increases in prey abundance. To assess the selectivity of a predator, we need to compare predator diet with quantitative information on the occurrence of prey taxa within the predator's environment. Such comparisons are few for seals, and the results are equivocal. In some studies seals ate the most numerically common prey (Thompson et al. 1991, Nilssen 1995, Nilssen et al. 1995), whereas in others they selected prey of a particular size (Sinclair et al. 1994), or less abundant prey (George-Nascimento et al. 1985).

Until recently, our knowledge of harp seal diet in the Northwest Atlantic has been based primarily on samples collected in different locations, seasons and years (Wallace \& Lawson 1997). This situation has improved with comprehensive studies in near- (Lawson et al. 
1995) and offshore areas of Newfoundland (Lawson \& Stenson 1997). However, there has been little concurrent data on the abundance and distribution of harp seal prey (Lawson et al. 1995), particularly Arctic cod Boreogadus saida, and for fish within harp seals' preferred size range ( 8 to $22 \mathrm{~cm}$ ). It is important to understand how the consumption of a particular prey species will vary with its availability to the predator (Harwood 1992). The answer will depend to an extent on the degree of selectivity exercised by the predator. This study provides the first quantitative evidence of foraging selectivity by harp seals in Newfoundland waters by comparing their diets to demersal trawl catches for nearand offshore areas in the winters of 1993 and 1994.

\section{MATERIALS AND METHODS}

Sampling regime. The harp seals used in this study were collected in offshore areas $(>30 \mathrm{~km}$ from the coast) during directed research trips (1993: $\mathrm{n}=13$, 1994: $\mathrm{n}=7)$, or collected in nearshore areas $(\mathrm{n}=133)$ by contract hunters (Fig. 1). No effort was made to restrict the sex or age of individuals killed, or the time of day at which they were collected. Visual surveys (Stenson \& Kavanagh 1993) and data from seals equipped with satellite-linked time depth recorders (Wildlife Computers, 16150 85th Street 226, Redmond, Washington 98052, USA) indicate that harp seals are distributed widely in waters around Newfoundland and Labrador, and that the area used in the offshore

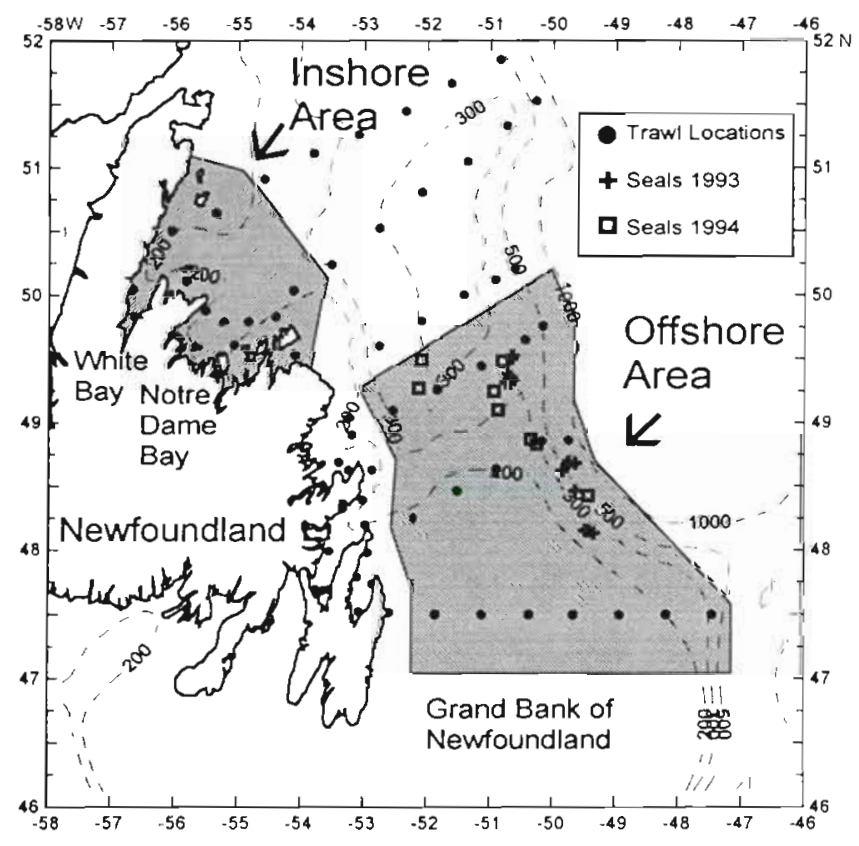

Fig. 1. Locations of harp seal Phoca groenlandica collections and sampling trawls in 1993 and 1994 component of this study is one of relatively high harp seal abundance. The methods for sample collection, stomach preparation and diet reconstruction are detailed in Lawson et al. (1995) and Lawson \& Stenson (1997).

Research trawling was carried out each year throughout the areas where seals were collected, at both nearshore and offshore locations. The trawling was done as part of a programme examining the winter distribution of juvenile fish in nearshore and offshore locations along the Northeast coast of Newfoundland (Dalley \& Anderson 1997). A line transect survey design was used, with trawling stations located $54 \mathrm{~km}$ (30 $\mathrm{n}$ miles) apart, running from the nearshore out across the shelf to the shelf break (Fig. 1). Trawl stations were located at distances less than $54 \mathrm{~km}$ apart when either the depth changed by more than $50 \mathrm{~m}$ or untrawlable locations were encountered within the nearshore. Trawling was done using a Campelen 1800 modified shrimp trawl fitted with $35 \mathrm{~cm}$ (14 in) rockhopper gear (Dalley \& Anderson 1997), which is specifically designed to catch small fish near the bottom (Godo \& Walsh 1992). Surveys were carried out in December 1992 (referred to as 1993) and December 1993 to January 1994 (referred to as 1994); harp seal collections were carried out in January and February of 1993 and 1994. A third year of trawling was carried out in December 1994 to January 1995 (referred to as 1995), although we do not have seal stomach samples from the winter of 1995 in the offshore area.

From the total survey area, we defined one nearshore area and one offshore area. The nearshore area is the area of collection of harp seals by landsmen along the coast of White Bay and Notre Dame Bay, Newfoundland (Fig. 1). The offshore area encompasses the locations where harp seals were collected each winter (January and February).

Selectivity estimation. Feeding selectivity was calculated using the alpha index $\left(\alpha_{i}\right)$ developed by Chesson (1978), where $\alpha$, was calculated as:

$$
\alpha_{1}=\frac{r_{1} / p_{i}}{\sum_{k=1}^{n} r_{k} / p_{k}}
$$

where $r_{1}$ is the proportion of prey type $i$ (among $k$ total prey types) in the seal diet and $p_{i}$ is the proportion in the water (as sampled by the trawl). In this paper, plotted selectivity values above or below the level of neutral selection indicate a positive or negative feeding preference by the seals, respectively. This index is widely acknowledged as the best indicator of feeding preferences due to the fact that it eliminates any differences that might occur in such indices due to abundance differences in the diet or the trawl (sampler). We considered 5 prey species of fish, which dominated the 
harp seal diet by weight: capelin Mallotus villosus, Arctic cod Boreogadus saida, American plaice Hippoglossoides platessoides, Greenland halibut, or turbot, Reinhardtius hippoglossoides, and Atlantic cod Gadus morhua. An important consideration in selectivity analyses is that the intersection set of species which occurs in both the diet and the trawl comprises a large proportion of the total stomach and trawl contents. In all cases, these 5 species accounted for more than $85 \%$ of total reconstructed content mass.

\section{RESULTS}

\section{Seal diets}

In the Northwest Atlantic, harp seals have a heterogeneous diet (a subset of which is presented in Table 1; Lawson \& Stenson 1995, 1997, Lawson et al. 1995, Wallace \& Lawson 1997). Although the diets of seals in each study area did not vary between 1993 and 1994 (Table 2), there was a significant difference in the relative proportions of each fish species eaten between the nearshore and offshore areas. Nearshore, seals predominantly ate Arctic cod, by mass, followed by relatively small amounts of capelin and little to no Atlantic cod, American plaice or Greenland halibut (combined data for 1993 and 1994; Fig. 2). Offshore, seals ate predominantly capelin, followed by Greenland halibut, and small amounts of American plaice,

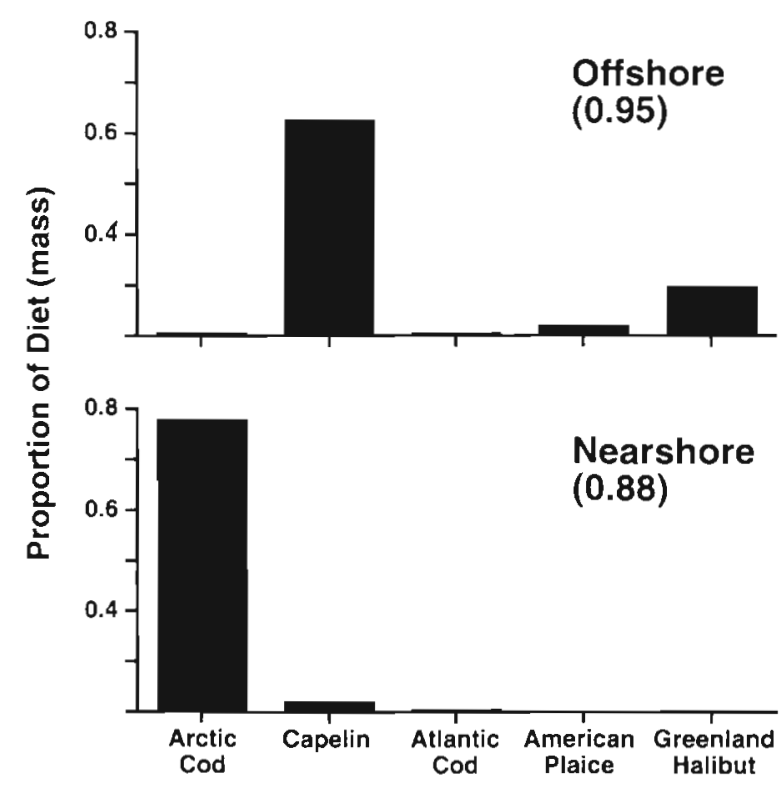

Fig. 2. Mean proportions (reconstructed wet mass) of 5 prey species in harp seal Phoca groenlandica stomachs and research trawl samples collected in nearshore and offshore Newfoundland waters, combined for 1993 and 1994

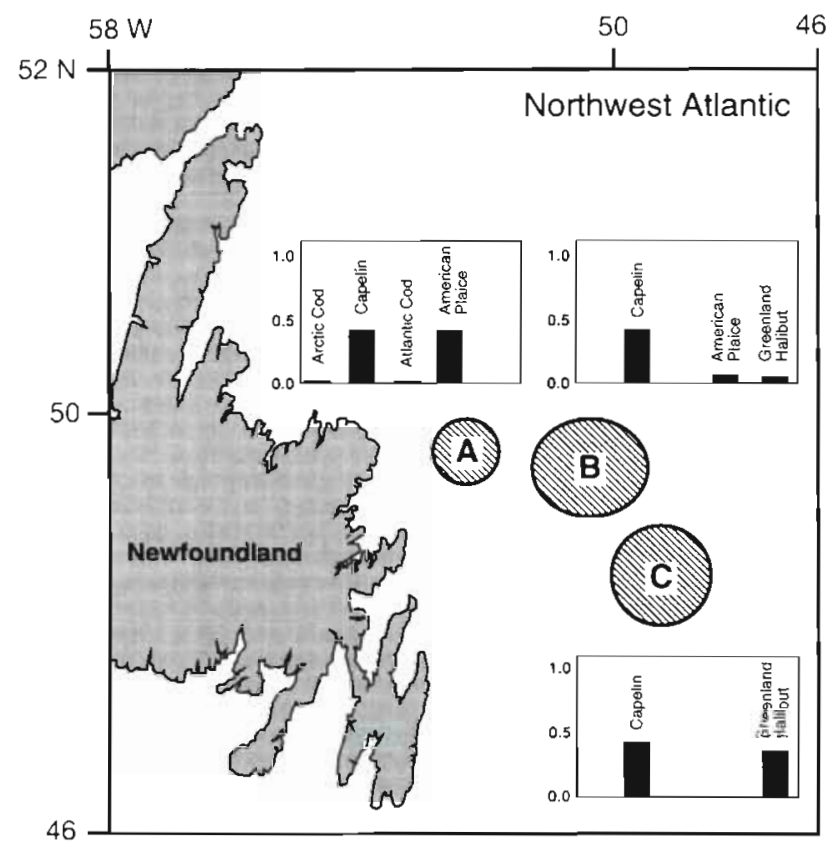

Fig. 3. Mean proportions (reconstructed wet mass) of 5 prey species in harp seal Phoca groenlandica stomachs collected in the 3 offshore study areas waters in 1993 and 1994

Atlantic cod and Arctic Cod. On average, these 5 species accounted for 88 and $95 \%$ of the total stomach content mass of seals from the nearshore and offshore areas, respectively.

To further explore the influence of sampling location we further subdivided the offshore area into 3 locales (Fig. 3). The first location (A) contained 2 harp seals sampled in 1994 which were collected over deep water ( 300 to $400 \mathrm{~m}$ ) south of Funk Island Bank. The second location (B) contained 8 seals from 1993 and 2 seals from 1994. This area was also over deep waters south of Funk Island Bank, but was essentially at the shelf break. The third location $(C)$, which was located immediately south of Area B over deep water at the shelf break, contained 5 seals from 1993 and 3 seals from 1994. The diets of these seals did not differ among years for each of these areas. However, harp seal diets did vary significantly among the 3 areas. In all cases, capelin occurred as a dominant component of the diet while the amounts of the other fish species varied. In Area $\mathrm{A}$, the diet was dominated by capelin and American plaice. Arctic cod and Atlantic cod occurred in low amounts, while Greenland halibut was not evident. In Area B, the diet was dominated by capelin, with American plaice and Greenland halibut occurring in low abundances. Arctic cod and Atlantic cod were not seen in the stomachs. In Area $\mathrm{C}$, the diet was dominated by capelin and Greenland halibut. Arctic cod and Atlantic cod did not occur in any significant amounts in the harp seal diets. 
Table 1. Percent total reconstructed wet mass of prey in harp seal Phoca groenlandica stomachs collected in near- and offshore study areas (see Fig. 1) of Newfoundland in January and February 1993 and 1994. Percent values less than 0.01 are denoted as 'trace'; blank entries denote species not found in the stomachs

\begin{tabular}{|c|c|c|}
\hline & Nearshore & Offshore \\
\hline \multicolumn{3}{|l|}{ Vertebrate prey } \\
\hline Atlantic herring & 8.25 & - \\
\hline Capelin & 0.70 & 63.33 \\
\hline Myctophidae & - & 0.08 \\
\hline Scaled lancetfish & - & 0.07 \\
\hline Gadoid sp. & 0.08 & 0.01 \\
\hline Atlantic cod & 2.42 & 2.20 \\
\hline Rock cod (Gadus ogac) & 0.74 & - \\
\hline Arctic cod & 78.01 & 1.85 \\
\hline Marlin spike (Nezumia bairdi) & - & 0.05 \\
\hline Sand lance & trace & - \\
\hline Fourline snakeblenny (Eumesogrammus praecisus) & 0.03 & - \\
\hline Eelpout sp. (Zoarcidae) & 2.45 & 1.92 \\
\hline Vahl's eelpout (Lycodes vahlii) & 0.08 & - \\
\hline Redfish sp. & 0.08 & 0.03 \\
\hline Sculpin sp. (Cottidae) & 0.02 & 0.04 \\
\hline Hookear sculpin (Artediellus spp.) & trace & 0.16 \\
\hline Moustache sculpin (Triglops murrayi) & trace & - \\
\hline Liparis sp. & 0.01 & 0.01 \\
\hline Pleuronectidae & 1.37 & 2.64 \\
\hline American plaice & - & 5.35 \\
\hline Greenland halibut & 0.67 & 6.11 \\
\hline Unknown fish & 0.02 & 1.08 \\
\hline \multicolumn{3}{|l|}{ Invertebrate prey } \\
\hline Gastropoda & trace & trace \\
\hline Teuthoidea (squid) & 2.43 & 6.14 \\
\hline Gonatus sp. & 1.90 & 6.90 \\
\hline Amphipoda & 0.01 & - \\
\hline Hyperiidae (crustacean) & 0.70 & 0.59 \\
\hline Gammaridea sp. (amphipod) & trace & - \\
\hline Mysidae sp. (mysid) & trace & - \\
\hline Euphausiacea (euphausiid) & 0.20 & - \\
\hline Thysanoessa sp. (euphausiid) & 0.35 & - \\
\hline Decapoda (crustacean) & trace & - \\
\hline Natantia (shrimp) & 0.01 & - \\
\hline Hippolytidae (shrimp) & trace & - \\
\hline Eualus fabricii (shrimp) & trace & 0.03 \\
\hline Eualus macilentus (shrimp) & 0.01 & - \\
\hline Eualus g. gaimardii (shrimp) & 0.02 & trace \\
\hline Lebbeus polaris (shrimp) & trace & - \\
\hline pandalus sp. (shrimp) & 0.06 & - \\
\hline
\end{tabular}

Table 2. Mean proportion of total reconstructed mass of 5 prey types in harp seal Phoca groenlandica stomachs and research trawl samples collected in January and February in near- and offshore Newfoundland waters, for 1993 and 1994 , used in calculations of Chesson's Index

\begin{tabular}{|lcccc|}
\hline \multicolumn{2}{c}{$\begin{array}{c}\text { Nearshore } \\
\text { Proportion of mass } \\
\text { in stomachs }\end{array}$} & $\begin{array}{c}\text { Proportion of mass } \\
\text { in trawl samples }\end{array}$ & $\begin{array}{c}\text { Offishore } \\
\text { Proportion of mass } \\
\text { in stomachs }\end{array}$ \\
\hline $\mathbf{1 9 9 3}$ & & & & 0.045 \\
Arctic cod & 0.779 & 0.328 & 0.001 & 0.138 \\
Capelin & 0.034 & 0.009 & 0.734 & 0.125 \\
Atlantic cod & 0.015 & 0.071 & 0.000 & 0.200 \\
American plaice & 0.000 & 0.141 & 0.049 & 0.123 \\
Greenland halibut & 0.000 & 0.049 & 0.079 & 0.059 \\
$\mathbf{1 9 9 4}$ & & & & 0.023 \\
Arctic cod & 0.838 & 0.411 & 0.460 & 0.147 \\
Capelin & 0.078 & 0.021 & 0.023 & 0.204 \\
Atlantic cod & 0.007 & 0.074 & 0.152 & 0.143 \\
American plaice & 0.000 & 0.134 & 0.133 & \\
Greenland halibut & 0.003 & 0.117 & & \\
\hline
\end{tabular}




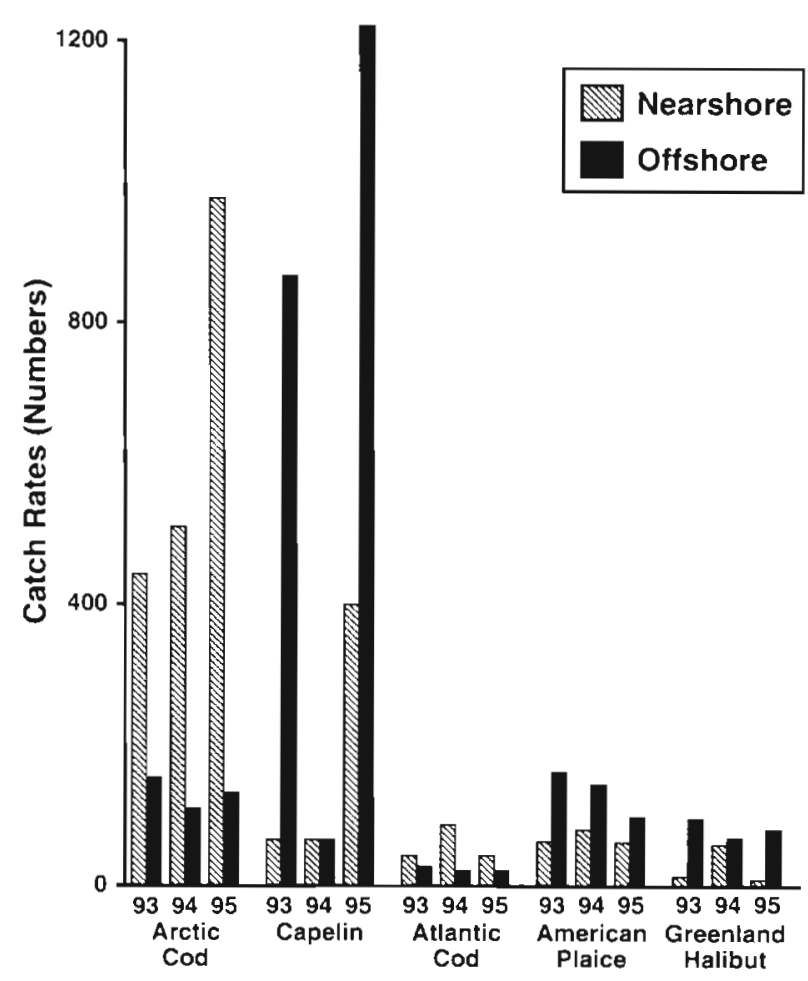

Fig. 4. Trawl catch rates of 5 prey species in nearshore and offshore areas during the 1993, 1994 (December 1993/January 1994) and 1995 (December 1994/January 1995) sampling periods

\section{Fish abundances}

The dominant fish species caught during the 3 survey years were Arctic cod and capelin; Arctic cod dominated nearshore and capelin offshore (Fig. 4). The only exception to this was the low abundance of capelin offshore in 1994. American plaice, Greenland halibut and Atlantic cod occurred in much lower numbers.

There were significant differences in abundances between nearshore and offshore locations. Nearshore, Arctic cod was the dominant fish caught each year, averaging 459 to 999 fish tow ${ }^{-1}$ (Fig. 4). All other species occurred at much lower abundances, being less than or equal to $84 \mathrm{fish}_{\text {tow }}{ }^{-1}$, with the exception of capelin in 1995 which averaged 394 fish tow $^{-1}$. Offshore, capelin was the most abundant species caught in 2 of the 3 years, averaging approximately 900 to $1300 \mathrm{fish}$ tow $\mathrm{w}^{-1}$ in those years. In 1994, capelin averaged less than 100 fish tow ${ }^{-1}$, which was surprisingly low compared with other years. The next most abundant species offshore were American plaice, Arctic cod and Greenland halibut, which averaged approximately 51 to $178 \mathrm{fish} \mathrm{tow}^{-1}$ each year. Atlantic cod was the least abundant fish species caught offshore in all 3 years (Fig. 4).
Comparing abundances within species for nearshore and offshore locations demonstrated a consistent pattern in all cases, except for capelin sampled offshore in 1994 (Fig. 4). In 2 of the 3 years capelin were 4 to 10 times more abundant offshore. Capelin were most abundant both nearshore and offshore in the 1995 survey.

Arctic cod were more abundant than the other 4 species nearshore in all years, with an apparent trend of increasing abundance from 1993 through to 1995. Offshore, Arctic cod were approximately 2 to 5 times less abundant than they were nearshore.

Atlantic cod were more abundant nearshore than offshore each year, when abundances included all cod captured from ages 0 to $3 \mathrm{yr}$ (Fig. 4). When the abundances of Atlantic cod are compared by age class it is apparent that 1 yr old cod were more abundant nearshore each year (Fig. 5). For age 2 Atlantic cod, abundances were higher nearshore in 1992 and lower in 1993 compared to the offshore. For age 3 Atlantic cod, abundances were higher offshore each year. These results suggest an ontogenetic shift in the distributions of juvenile cod from nearshore to offshore locations as they grow from age 1 to $3 \mathrm{yr}$.

American plaice were approximately twice as abundant offshore as nearshore in all 3 years, with a trend of decreasing abundance offshore and no apparent trend nearshore. Greenland halibut were more abundant offshore than nearshore each year.

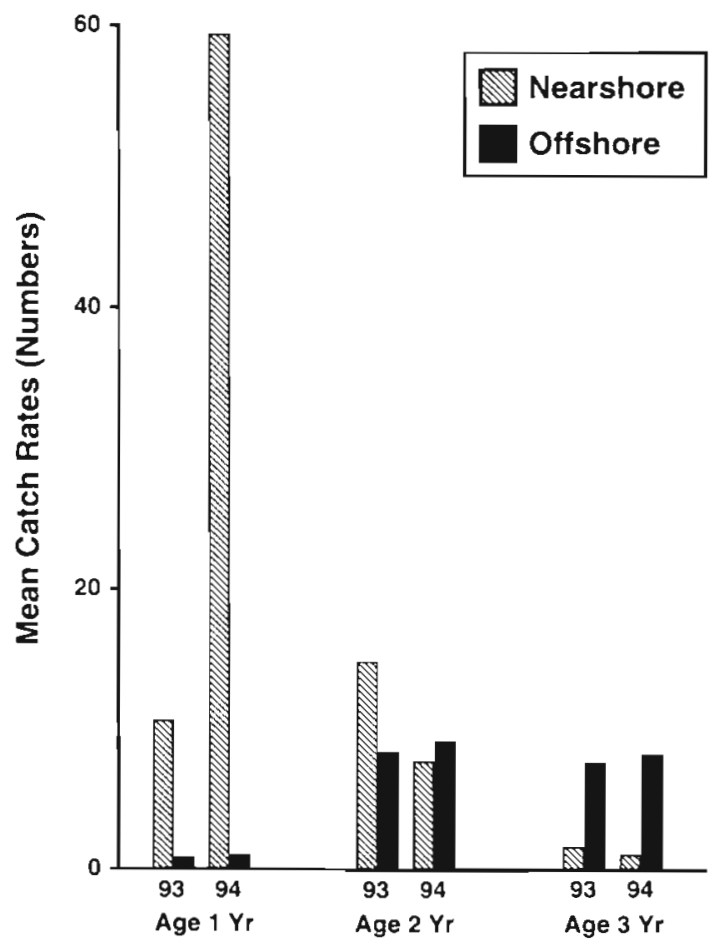

Fig. 5. Mean trawl catch rates of Atlantic cod, aged 1 to 3 yr, in nearshore and offshore areas for 1993 and 1994 


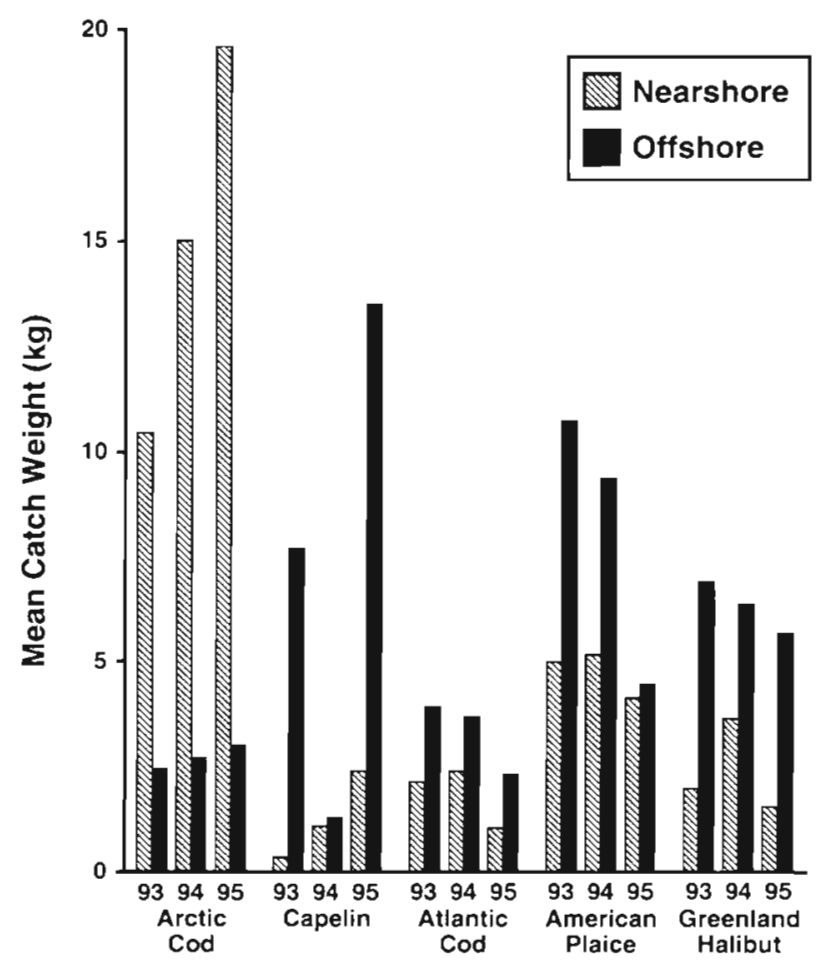

Fig. 6. Mean trawl catch weights of 5 prey species in nearshore and offshore areas during the 1993, 1994 and 1995 sampling periods

Comparison of fish biomass between nearshore and offshore locations were similar to abundances, with the notable exception of Atlantic cod (Fig. 6). The biomass of Atlantic cod was greater offshore each year, for Atlantic cod of all ages. This result is primarily due to the greater offshore abundance of age 3 fish.

\section{Fish distributions in offshore waters}

Fish distributions were examined only for the offshore area in order to compare them with geographic differences in seal diets observed offshore. Nearshore, it was not possible to relate geographic differences in prey and seal distribution as the precise locations of the seal samples were not known.

The distributions of fish offshore did not vary significantly among years for any single species, but there were obvious differences in the distributions among species. Arctic cod were most abundant within the shoreward half of the area as well as the northern Grand Bank to the south (Fig. 7). Capelin were abundant throughout most of the offshore area, although their distributions were somewhat similar to Arctic cod (Fig. 7). Atlantic cod were most abundant in the northern part of the offshore study area, with low abundances occurring over the northern Grand Bank
(Fig. 7). American plaice were distributed abundantly throughout most of the offshore area, although there appeared to be a trend of lower abundances in the northern part during 1994 (Fig. 7). Greenland halibut were most abundant in the northern part of the offshore area, where highest abundances occurred in deep water ( $>400 \mathrm{~m}$; Fig. 7). No Greenland halibut were captured in the shallow waters $(<100 \mathrm{~m})$ of the northern Grand Bank.

\section{Seal feeding selectivity}

Harp seals preferentially selected capelin in both nearshore and offshore areas each year, as indicated by consistently positive Chesson values (Fig. 8). This result occurred even though there were significant differences among areas in the abundance of capelin sampled by the trawl and the proportion of capelin in the harp seal diets. Selectivity for Arctic cod varied between nearshore and offshore areas. Nearshore, Arctic cod were a preferred prey both years, on the same order as capelin. However, offshore, Arctic cod were negatively selected in 1993 and neutrally selected in 1994. Atlantic cod were neutrally selected by harp seals, being neither preferred or rejected as a prey item for nearshore and offshore areas each year. American plaice were neutrally selected by harp seals in the offshore area. Selectivity values for Greenland halibut were near neutral in offshore areas each year, whereas they appeared to be negatively selected in nearshore areas in 1994. The low values of selectivity estimated for Atlantic cod, American plaice and Greenland halibut resulted from their absence in the diet. While these calculations indicate very low selection, in each case they occurred where the abundances of these fish species were lowest and, therefore, should be considered with caution.

Harp seal feeding selectivity calculated for the 3 different regions within the offshore area (see Fig. 2) indicated that capelin were a preferred prey item in Areas $A$ and $B$, while they were neutrally selected in Area C (Fig. 9). American plaice appeared to be a preferred prey item in Area B, while Greenland halibut were strongly selected in Area C. In no instance were any of the 5 fish species negatively selected as a prey item in Area C.

\section{DISCUSSION}

Comparisons of seal diet with local prey availability have shown that several seal species (Thompson et al. 1991, Sinclair et al. 1994), including harp seals in the Northeastern Atlantic (Nilssen et al. 1995, Lindstrøm et 

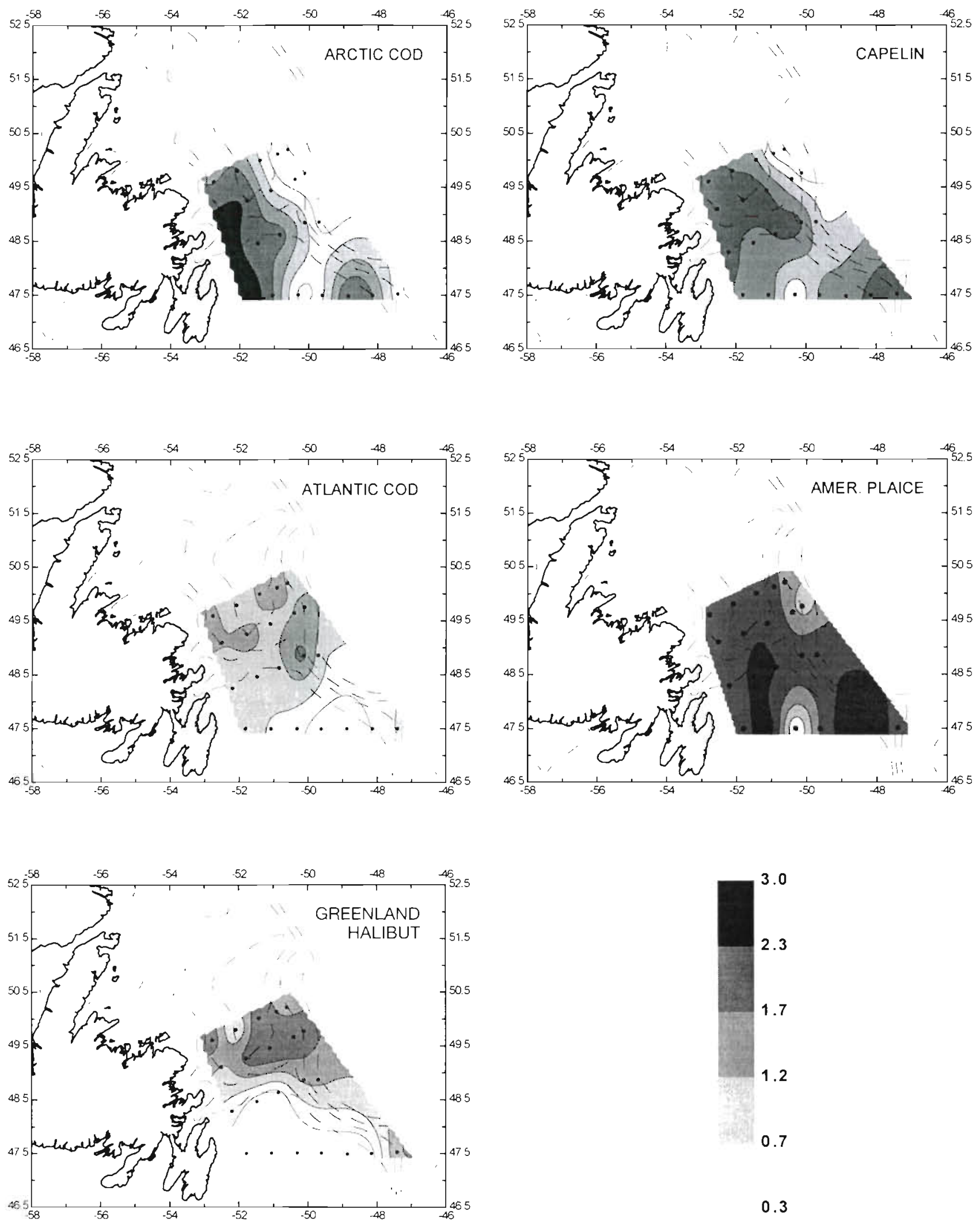

Fig. 7. Offshore distributions of Arctic cod, capelin, Atlantic cod, American plaice and Greenland halibut in 1993 (December 1993/January 1.994). The data are $\log _{10}$ of the numbers of fish caught per 30 min tow, with scale intervals from light to dark shades for values of $0.30,0.70,1.2,1.7,2.3$, and 3.0 . These values were spatially extrapolated using kriging 


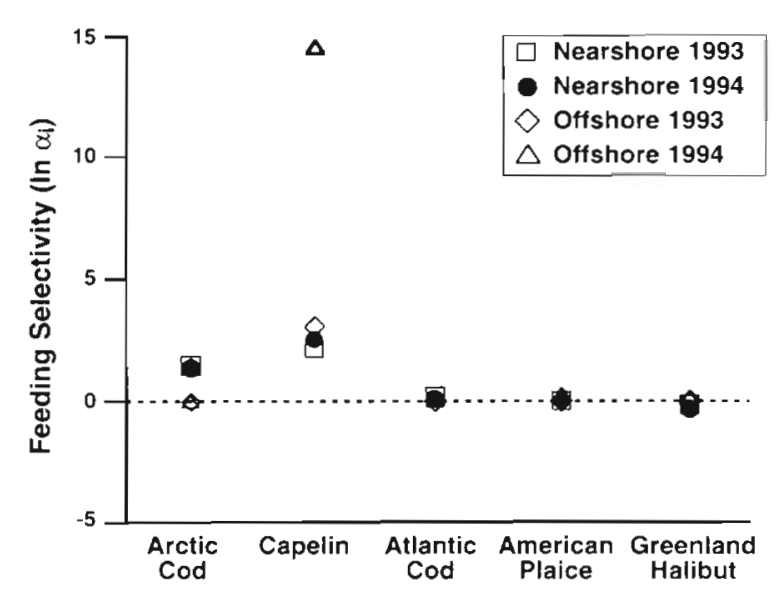

Fig. 8. Harp seal Phoca groenlandica feeding selectivity calculated for 5 prey types. Chesson's alpha index for species $i\left(\alpha_{i}\right)$ is plotted as $\log _{\mathrm{e}}$. The dashed line indicates the estimate of neutral selectivity

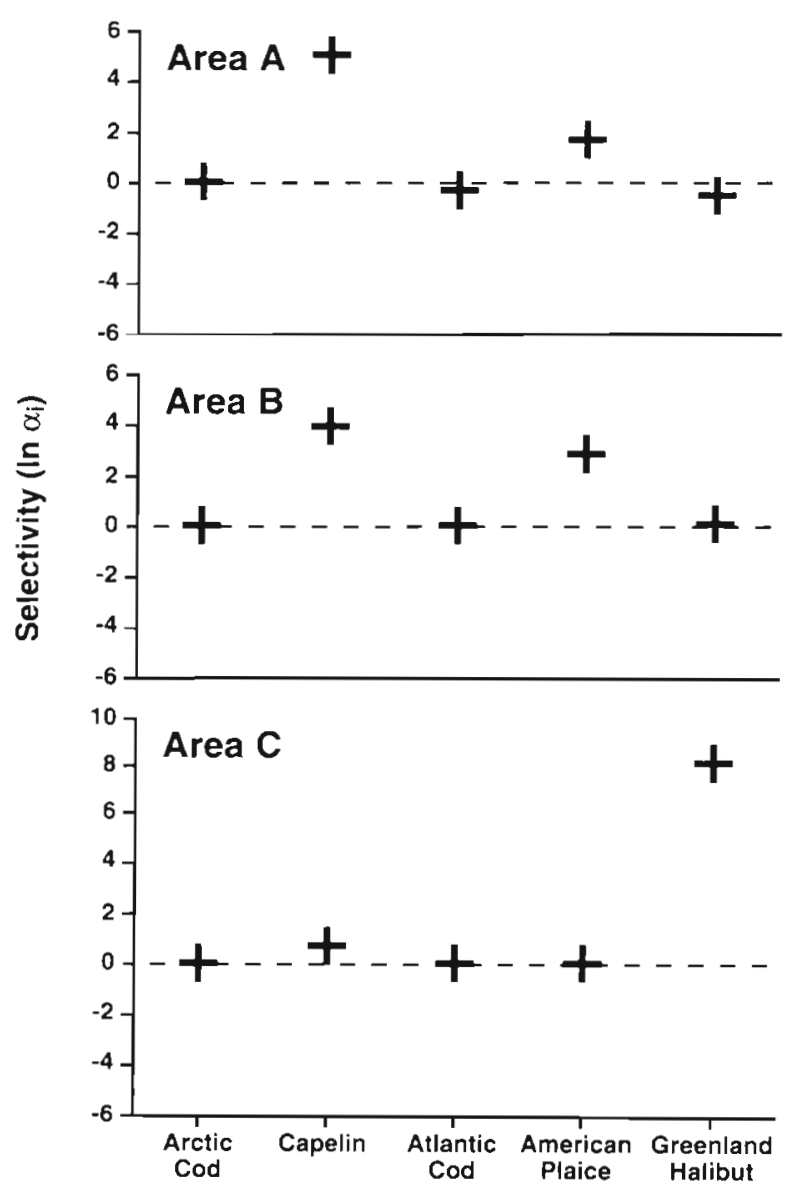

Fig. 9. Harp seal Phoca groenlandica feeding selectivity calculated for 5 prey types in each of the 3 offshore subareas (see Fig. 2). Chesson's alpha index for species $i\left(\alpha_{i}\right)$ is plotted as $\log _{e}$. The dashed line indicates the estimate of neutral selectivity al. 1996), exhibit feeding preferences for particular types and sizes of prey that are independent of local prey abundance. The results of this study are exciting since they both corroborate what has been reported for harp seal feeding preferences based on stomach contents (Lawson et al. 1995, Lawson \& Stenson 1997) and fatty acids (Lassner 1996), and suggest that these seals may be actively choosing their prey.

The Chesson's index of selectivity suggests that capelin was strongly selected for by harp seals in both near- and offshore waters. This supports dietary evidence of a preference for capelin seen prior to 1986 when this species was predominant in harp seals' diets in nearshore areas (Lawson \& Stenson 1995). Also, dietary data show that the diet of harp seals in offshore waters is almost $90 \%$ capelin, by mass (Lawson \& Stenson 1997), even though they had the opportunity to consume other prey.

The strong selectivity for capelin is an important result from a seal energetics point of view, since harp seals digest capelin more efficiently than they do most other harp seal prey (Lawson et al. 1997), and offshore capelin have relatively high energy densities compared to most other prey species (Lawson et al. 1998). If this selectivity is reflected in their diet, the total consumption of capelin relative to other prey types by the harp seal population will be higher, and the population will consume a relatively smaller total prey biomass to satisfy its energy demands. Further, such selectivity means that harp seals' consumption of juvenile Atlantic cod would be lower than expected if they were foraging randomly (at least in the nearshore areas).

In fact, Atlantic cod were rarely found in the stomachs of nearshore seals (Lawson et al. 1995), or offshore seals collected independently of commercial cod trawls (Lawson \& Stenson 1997). The absence of Atlantic cod did not appear to be due to the unavailability of this prey since hooded seal Cystophora cristata stomachs collected concurrently with harp seals did contain more than $10 \%$ Atlantic cod by mass (Lawson \& Stenson unpubl. data). The Chesson index supports this finding by showing that harp seals were neutrally or negatively selecting this fish species. The low selectivity values for Atlantic cod, plaice and Greenland halibut resulted from their absence from the seal stomachs. The selectivity indices were calculated when the abundances of these fish species were lowest. Therefore, these results should be considered with caution until a similar selectivity study can be conducted in areas where juvenile cod are abundant, such as nearshore Northeastern Newfoundland (Dalley \& Anderson 1997).

From 1986 onward, Arctic cod have predominated in harp seals' nearshore diets (Lawson \& Stenson 1995, Lawson et al. 1995), which may be a function of the 
notable influx of this prey species into Newfoundland waters (Lilly et al. 1994). This study suggests that harp seals prefer this species in nearshore areas, where it is abundant in both the environment and seal stomachs, but do not have the same level of preference for them as a prey choice when the seals are offshore. This implies a geographic difference in feeding selectivity that would be interesting to explore further, although we can only speculate why such a difference might occur. This may relate to the similar relative energy densities of Arctic cod and capelin in nearshore waters, regardless of season, but not in offshore areas (Lawson \& Stenson 1997). If the energy densities of these 2 species influence harp seal feeding behaviour, we would expect that seals would have a preference for Arctic cod in nearshore waters due to its greater relative abundance and similar energy density to capelin. However, in offshore waters capelin's greater energy density and abundance would favour a selection for this species. Information must be obtained for other prey-related factors, such as abundance, catchability, handling time and distribution across and within the water column, which might affect harp seal prey choice since it seems unlikely they are choosing prey based on energy content alone. The relative speed and exceptional diving capability of harp seals mean they can choose from a broad range of potential prey, and their long life and intelligence imply they can learn which prey are better choices.

We assumed the trawls provided a reasonable index of the relative abundances of fish species throughout the depths at which seals where feeding. Dive data were obtained from harp seals equipped with satellitelinked time depth recorders in 1995 and 1996, and from times when seals were within the study areas. These records indicated that, although most of their dives tended to be shallow, harp seals frequently dove to depths equivalent to the bottom (100 to $300 \mathrm{~m}$; G. Stenson \& B. Sjare unpubl. data) and were clearly capable of sampling prey throughout the water column. Capelin and Arctic cod are usually regarded as pelagic species, although capelin may have been distributed deeper in the water column during the time of this study, and are regularly encountered in bottom trawls. Until technology permits us to determine precisely the times and depths at which seals are capturing their prey, further selectivity studies will be designed to provide concurrent pelagic and demersal fish abundance estimates.

A potential criticism of this study is the non-synopticity of the seal and trawl samples. However, the distributions and abundances of the fish species were unlikely to be different from the time they were collected and the time the seals were collected. This is inferred by the relatively stable pattern of fish distrib- ution and abundance observed over the $3 \mathrm{yr}$ of sampling. In addition, the winter period is a time when species of fish are, generally, overwintering and nonmigratory, and so might be considered fairly stationary in a statistical sense. Nonetheless, it would be preferable to sample the seals and prey simultaneously, as has been done in Norway (Nilssen et al. 1995, Lindstrom et al. 1996). On a smaller scale, seal stomachs can empty in a short time (e.g. as little as $1 \mathrm{~h}$ for harbour seals; Markussen 1993); so even small differences in the timing of seal and trawl sampling may be significant. A directed study to pursue the question of selectivity should rely on several measures of diet (gastrointestinal contents including the intestines, fatty acids and stable isotopes), and concurrent prey assays at depths frequented by the harp seals.

The most compelling result of this study is that seal diets matched the abundances of fish sampled between nearshore and offshore areas. Nearshore, the diet and trawl catches were dominated by Arctic cod, whereas offshore it was capelin. However, the selectivity calculations indicate that capelin were preferred in both areas. This is an important result from the perspectives of both harp seal bioenergetics and fish population dynamics. We must conduct further directed studies to test these predictions of harp seal feeding preferences. Concurrent seal diet assays and fish abundance surveys are one means to quantify foraging selectivity; particularly as ecologists begin to gather better data on predators and their prey.

Acknowledgements. We thank D. McKinnon, W. Penney and D. Wakeham (Department of Fisheries and Oceans, St. John's, NF) for collecting and processing the seal samples. We thank D. Davis for assisting with the analyses of the trawling data and E. McDonald, C. March, A. Murphy, and G. Redmond (Department of Fisheries and Oceans, St. John's, NF) for data collection and sample processing of the fish data. B. Sjare (Department of Fisheries and Oceans, St. John's, NF) reviewed an earlier draft of the manuscript. This is Ocean Sciences contribution no. 276, and was funded partly by the Canadian Centre for Fisheries Innovation

\section{LITERATURE CITED}

Chesson J (1978) Measuring preference in selective predation. Ecology 59:211-215

Dalley EL, Anderson JT (1997) Age-dependent distribution of demersal juvenile Atlantic cod (Gadus morhua) in inshore/offshore northeast Newfoundland. Can J Fish Aquat Sci 54:168-176

Finley KJ, Bradstreet MSW, Miller GW (1990) Summer feeding ecology of harp seals (Phoca groenlandica) in relation to Arctic cod (Boreogadus saida) in the Canadian high Arctic. Polar Biol 10:609-618

George-Nascimento MA, Bustamente R, Oyarzun C (1985) Feeding ecology of the South American sea lion Otaria flavescens: food contents and food selectivity. Mar Ecol Prog Ser 21:135-143 
Godo OR, Walsh SJ (1992) Escapement of fish during bottom trawl sampling-implications for resource assessment. Fish Res 13:281-292

Harwood J (1992) Assessing the competitive effects of marine mammal predation on commercial fisheries. S Afr J Mar Sci 12:689-693

Lassner J (1996) Fatty acid composition of harp seal (Phoca groenlandica) blubber as an indicator of diet. Honours thesis, Dalhousie University, Halifax, NS

Lawson JW, Magalhāes AM, Miller EH (1998) Important prey species of marine vertebrate predators in the Northwest Atlantic: proximate composition and energy density. Mar Ecol Prog Ser (in press)

Lawson JW, Noseworthy E, Miller EH (1997) Variation in assimilation and digestive efficiency of captive harp seals (Phoca groenlandica) on different diets. Can J Zool 75: $1285-1291$

Lawson JW, Stenson GB (1995) Historic variation in the diet of harp seals (Phoca groenlandica) in the northwest Atlantic. In: Blix AS, Walløe L, Ultang $\varnothing$ (eds) Whales, seals, fish and man. Elsevier Science B.V., Tromsø, Norway, p 261-269

Lawson JW, Stenson GB (1997) Diet of Northwest Atlantic harp seals (Phoca groenlandica) in offshore areas. Can J Zool 75:2095-2106

Lawson JW, Stenson GB, McKinnon DG (1995) Diet of harp seals (Phoca groenlandica) in nearshore waters of the northwest Atlantic during 1990-93. Can J Zool 73: $1805-1818$

Lilly GR, Hop H, Stansbury DE, Bishop CA (1994) Distribution and abundance of polar cod (Boreogadus saida) off southern Labrador and eastern Newfoundland. Theme session on non-target species. ICES CM 1994/O:6

Lindstrøm U, Harbitz A, Haug T, Nilssen KT (1996) Do harp seals Phoca groenlandica exhibit particular prey preferences? Marine mammals committee. ICES CM 1996/N:2

Markussen NH (1993) Transit time of digesta in captive harbour seals (Phoca vitulina). Can J Zool 71:1071-1073

Editorial responsibility: Otto Kinne (Editor),

Oldendorf/Luhe, Germany
Mårtensson PE, Lager Gotass AR, Nordøy ES, Blix AS (1996) Seasonal changes in energy density of prey of northeast Atlantic seals and whales. Mar Mamm Sci 12:635-640

Nilssen KT (1995) Seasonal distribution, condition and feeding habits of Barents Sea harp seals (Phoca groenlandica). In: Blix A.S, Walløe L, Ultang $\varnothing$ (eds) Whales, seals, fish and man. Elsevier Science BV, Tromsø, p 241-254

Nilssen KT, Haug T, Potelov V, Timoshenko YK (1995) Feeding habits of harp seals (Phoca groenlandica) during early summer and autumn in the northern Barents Sea. Polar Biol 15:485-493

Reijnders PJH, Brasseur S, van der Toorn J, van der Wolf $\mathrm{P}$, Boyd I, Harwood J, Lavigne DM, Lowry L (1993) Seals, furs seals, sea lions, and walrus. Status survey and conservation action plan. IUCN Conservation Action Plan, SSC Seal Specialist Group, International Union for Conservation of Nature and Natural Resources, Gland

Sergeant DE (1965) Migrations of harp seals Pagophilus groenlandicus (Erxleben) in the Northwest Atlantic. J Fish Res Bd Can 22:433-463

Sinclair E, Loughlin T, Pearcy W (1994) Prey selection by northern fur seals (Callorhinus ursinus) in the eastern Bering Sea. Fish Bull 92:144-156

Steimle FW Jr, Terranova RJ (1985) Energy equivalents of marine arganisms from the continental shelf of the temperate Northwest Atlantic, J Northw Atl Fish Sci 6: $117-124$

Stenson GB, Kavanagh DJ (1993) Distribution of harp and hooded seals in offshore waters of Newfoundland. NAFO Sci Counc Stud 21:121-142

Thompson PM, Pierce GJ, Hislop JRG, Miller D, Diack JSW (1991) Winter foraging by common seals (Phoca vitulina) in relation to food availability in the Inner Moray Firth, N.E. Scotland. J Anim Ecol 60:283-294

Wallace SD, Lawson JW (1997) A review of stomach contents of harp seals (Phoca groenlandica) from the Northwest Atlantic: an update. Tech Rep 97-01. International Marine Mammal Association, Guelph, ON

Submitted: July 30, 1997; Accepted: November 17, 1997 Proofs received from author(s): February 19, 1998 